\title{
Outbreak of West Nile virus infection among humans in Serbia, August to October 2012
}

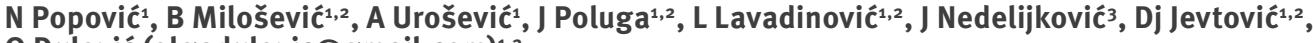

O Dulović (olgadulovic@gmail.com) ${ }^{1,2}$

1. Clinic for Infectious and Tropical Diseases, Clinical Centre Serbia, Belgrade, Serbia

2. Medical faculty, University of Belgrade, Belgrade, Serbia

3. Institute of Virology, Vaccines and Sera 'Torlak', Belgrade, Serbia

Citation style for this article:

Popović N, Milošević B, Urošević A, Poluga J, Lavadinović L, Nedelijković J, Jevtović D, Dulović O. Outbreak of West Nile virus infection among humans in Serbia, August to October 2012. Euro Surveill. 2013;18(43):pii=20613. Available online: http://www.eurosurveillance.org/ViewArticle.aspx?Articleld=20613

Article submitted on 24 November 2012 / published on 24 October 2013

We describe the first reported outbreak of West Nile virus (WNV) infection in humans in Serbia in August to October 2012 and examine the association of various variables with encephalitis and fatal outcome. Enzyme-linked immunosorbent assay (ELISA) was used for detection of WNV-specific IgM and IgG antibodies in sera and cerebrospinal fluid. A total of 58 patients (mean age: 61 years; standard deviation: 15) were analysed: 44 were from Belgrade and its suburbs; 52 had neuroinvasive disease, of whom 8 had meningitis, while 44 had encephalitis. Acute flaccid paralysis developed in 13 of the patients with encephalitis. Age over 60 years and immunosuppression (including diabetes) were independently associated with the development of encephalitis in a multivariate analysis: odds ratio (OR): $\mathbf{4 4 . 8}$ (95\% confidence interval (CI): 4.93-408.59); $p=0.001$ (age over 6o years); OR: 10.76 (95\% Cl: 1.06-109.65); $\mathrm{p}=0.045$ (immunosuppression including diabetes). Respiratory failure requiring mechanical ventilation developed in 13 patients with encephalitis. A total of 35 patients had completely recovered by the time they were discharged; nine patients died. The presence of acute flaccid paralysis, consciousness impairment, respiratory failure and immunosuppression (without diabetes) were found to be associated with death in hospital in a univariate analysis ( $p<0.001, p=0.007, p<0.001$ and $p=0.010$, respectively).

\section{Introduction}

West Nile Virus (WNV) is a single-stranded RNA, mosquito-borne virus that belongs to the Flaviviridae family. It was first identified in the West Nile district of Uganda in 1937 in a woman who presented with a mild febrile illness [1]. During the next decades, the virus spread through Africa and Asia: by the mid2oth century, it had appeared in Europe [2]. The first cases were reported in Israel (in the World Health Organization European Region) in the 1950s, followed by France in 1962-63 [2]. The first large outbreak in humans in Europe was in Romania, in 1996-97, and subsequent outbreaks were also reported in Russia in 1999 and Spain in 2004 [3-5]. Recently, ecological conditions were favourable for the spread of WNV in the Mediterranean, central and south-east Europe, causing outbreaks in countries neighbouring Serbia: Italy in 2008-10, Hungary in 2008, Albania and the former Yugoslav Republic of Macedonia in 2011 [6-9]. In Greece in 2010, 262 cases of WNV human infection were reported, including 197 patients with neuroinvasive disease [10]. In the following year (2011), there was another outbreak in Greece [11]. At the same time, epidemics were recorded in Turkey in 2010 and 2011, and Russia in 2010 [12,13]. Taken together, these data indicated that WNV was circulating in nearby countries, suggesting that human cases of WNV infection could be expected in Serbia as well. In 2011, Lupulovic et al. reported the first serological evidence of WNV infection in Serbia as a zoonosis: they showed that 42 (12\%) of 349 horses analysed had WNV-specific neutralising antibodies [14].

It was first thought that WNV caused a mild, influenzalike disease, but the epidemics in Romania in 1996-97 and New York in 1999 demonstrated that this virus was also a neuropathogen, causing severe neurological disease $[3,15]$. Today, it is known that around $20 \%$ of people who become infected have symptomatic disease, and one of 150 infected has neuroinvasive disease, which can present as meningitis, encephalitis and acute flaccid paralysis (AFP) $[16,17]$. The clinical presentation of AFP usually resembles that of poliomyelitis and AFP has been recognised as a separate entity of neuroinvasive disease due to WNV infection [16]. Possible, but extremely rare, clinical presentations of WNV infection are chorioretinitis, pancreatitis, fulminant hepatitis and myocarditis [18-20].

We describe here the clinical and epidemiological characteristics and outcome of patients in the first reported outbreak of WNV infection in humans in Serbia in 2012. We also sought to determine the association of various variables with encephalitis due to WNV infection and fatal outcome. 


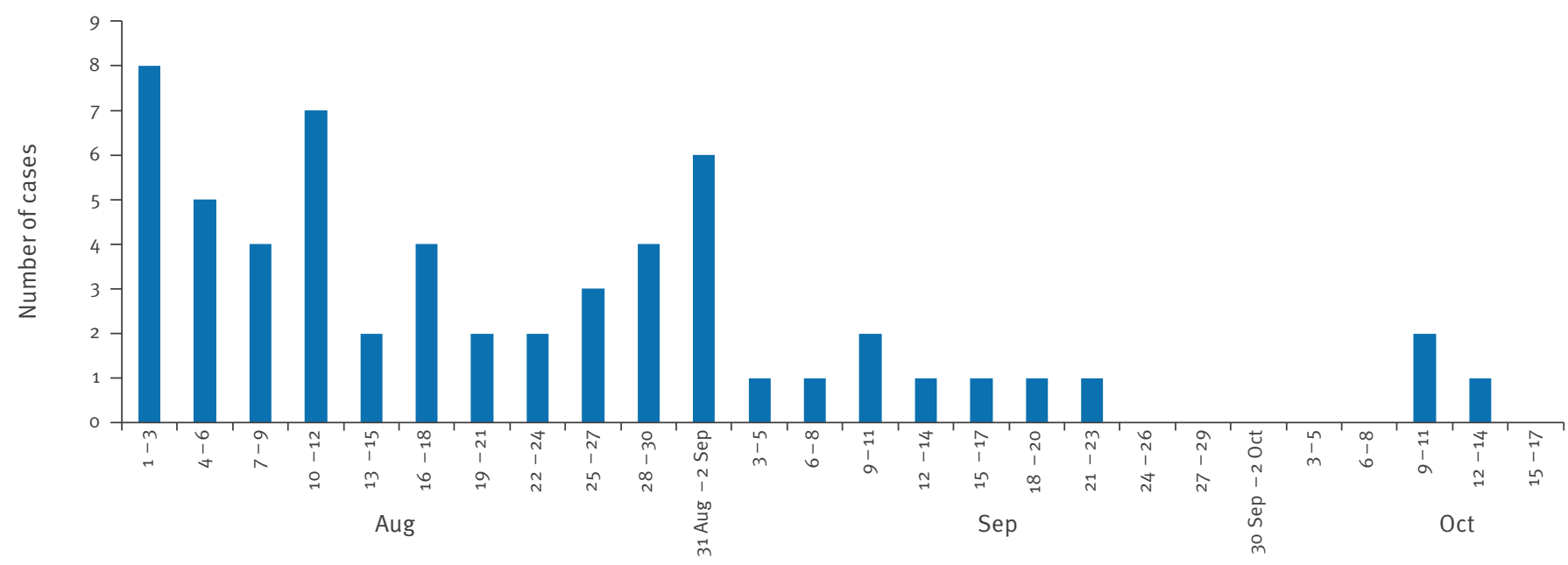

Date of symptom onset in 2012 (3-day interval)

\section{Methods}

\section{Inclusion criteria}

At the Clinic for Infectious and Tropical Diseases, Clinical Centre Serbia in Belgrade, we carry out specific screening for WNV infection (we have no data about specific screening in other medical centres in Serbia). In the study presented here, we enrolled patients with acute WNV infection treated at our clinic from 1 August to 31 October 2012.

\section{Case definition}

Diagnostic criteria for probable and confirmed cases were established according to the European Union case definition for West Nile fever [21]. A person with fever $\left(\geq 37.5^{\circ} \mathrm{C}\right)$, meningitis or encephalitis met the clinical criteria.

Patients presenting with meningitis, encephalitis and/ or AFP were considered as having neuroinvasive disease. Meningitis was defined as the presence of fever, clinical signs of meningeal inflammation, including headache, nuchal rigidity, Kernig's sign or Brudzinski signs, photophobia or phonophobia, and the presence of cerebrospinal fluid (CSF) pleocytosis (>5 leucocytes/ $\mathrm{mm}^{3}$; norm: $0-5$ leucocytes $/ \mathrm{mm}^{3}$ ), elevated protein levels (>0.45 g/L; norm: $0.15-0.45 \mathrm{~g} / \mathrm{L}$ ) and normal (2.6$3.1 \mathrm{mmol} / \mathrm{L}, 50-60 \%$ of serum glucose levels) or mildly decreased $(2.4-2.6 \mathrm{mmol} / \mathrm{L})$ CSF glucose level $[22,23]$.

Encephalitis was defined as the presence of fever, encephalopathy (decreased or altered level of consciousness, lethargy or personality change) and/or focal neurological signs (weakness, cranial nerve palsies), seizures or movement disorders (tremor, parkinsonism, ataxia) and the presence of CSF pleocytosis ( $/ 5$ leucocytes $/ \mathrm{mm}^{3}$ ), elevated protein levels (>0.45 $\mathrm{g} / \mathrm{L}$ ), and normal $(2.6-3.1 \mathrm{mmol} / \mathrm{L}, 50-60 \%$ of serum glucose levels) or mildly decreased $(2.4-2.6 \mathrm{mmol} / \mathrm{L}) \mathrm{CSF}$ glucose level $[22,23]$.

AFP was defined as acute onset of limb weakness or paralysis with progression over 48 hours. Limb weakness was characterised by at least two of the following: asymmetry; areflexia/hyporeflexia of affected limbs; absence of pain; electrodiagnostic studies consistent with an anterior horn cell lesion; CSF pleocytosis $\left(>5\right.$ leucocytes $/ \mathrm{mm}^{3}$ ) and elevated protein levels (>0.45 $\mathrm{g} / \mathrm{L})[22]$.

Laboratory criteria for case confirmation was the presence of at least one of the following: (i) isolation of WNV from blood or CSF; (ii) detection of WNV nucleic acid in blood or CSF; (iii) WNV-specific antibody response (IgM) in CSF; (iv) WNV IgM high titre and detection of WNV IgG, and confirmation by neutralisation [21].

In our study, all patients who were diagnosed as confirmed cases had a WNV-specific IgM antibody response in CSF. Isolation of the virus and reverse transcription-polymerase chain reaction (RT-PCR) for detection of WNV nucleic acid were not performed.

Laboratory criteria for a probable case were the presence of WNV-specific IgM and IgG antibody response in serum in the absence of WNV-specific IgM antibodies in CSF.

None of the patients had a history of flavivirus vaccination. All of the patients with neuroinvasive disease had sterile CSF bacterial cultures and negative serological tests for other common causes of viral encephalitis, especially herpes viruses. 


\section{Serology tests}

Acute phase CSF and acute and convalescence phase serum samples (on the first day of hospitalisation and within 10-14 days after symptom onset) were collected to be tested for the presence of IgM and IgG WNVspecific antibodies. The samples were transported at $4^{\circ} \mathrm{C}$ and stored at $-25{ }^{\circ} \mathrm{C}$ until testing. Samples were analysed by enzyme-linked immunosorbent assay (ELISA) (Anti-West Nile Virus ELISA (IgM) and AntiWest Nile Virus ELISA (IgG), EUROIMMUN, Medizinische Labordiagnostika AG), which was performed by the National Reference Laboratory for Arboviruses of the Institute of Virology, Vaccines and Sera 'Torlak' in Belgrade.

\section{Patient data}

Patients' demographic characteristics (age, sex, region of residence within the country), comorbidity (hypertension, cardiovascular disease including cardiomyopathy, coronary disease, previous stroke and myocardial infarction, diabetes, immunosuppression), presenting symptoms and signs, clinical findings, biochemical analysis of blood and CSF along with the results of serological tests were recorded, as well as the functional outcome at hospital discharge. Immunosuppression was defined as a state of reduced immune response due to, for example, immunosuppressive therapy, malignancy and radiotherapy. Consciousness impairment was classified as mild if the Glasgow Coma Score (GCS) was >8, and serious if the GCS was $\leq 8$.

\section{Statistical analyses}

All data were analysed using descriptive and analytical statistics. For the univariate analysis, chi-square test and Fisher's exact test were applied for categorical variables and Student's t-test for continuous variables. Binary logistic regression analysis was performed to estimate the independent association of several variables with the development of encephalitis. Covariates were selected for entry into the model based on the results of univariate analysis ( $p<0.2)$ and judgement of clinical importance (i.e. if a known risk factor for encephalitis). Odds ratios (ORs) and 95\% confidence intervals (Cls) were obtained.

The association of several variables with fatal outcome was analysed using univariate analysis: multivariate analysis could not be performed due to the small number of deaths. The Statistical Package for the Social Sciences (SPSS) software for Windows (version 17.0) was used for statistical analysis. Statistical significance was set at 0.05 .

\section{Results}

A total of 58 patients who met the diagnostic criteria were included in our study. Of these, 45 were diagnosed as confirmed cases and 13 as probable cases, according to the case definition. The first cases had symptom onset in the beginning of August 2012 and the last in the first half of October (Figure 1).

\section{FIGURE 2}

Distribution of human cases of West Nile virus infection, Serbia, August-October $2012(n=58)$

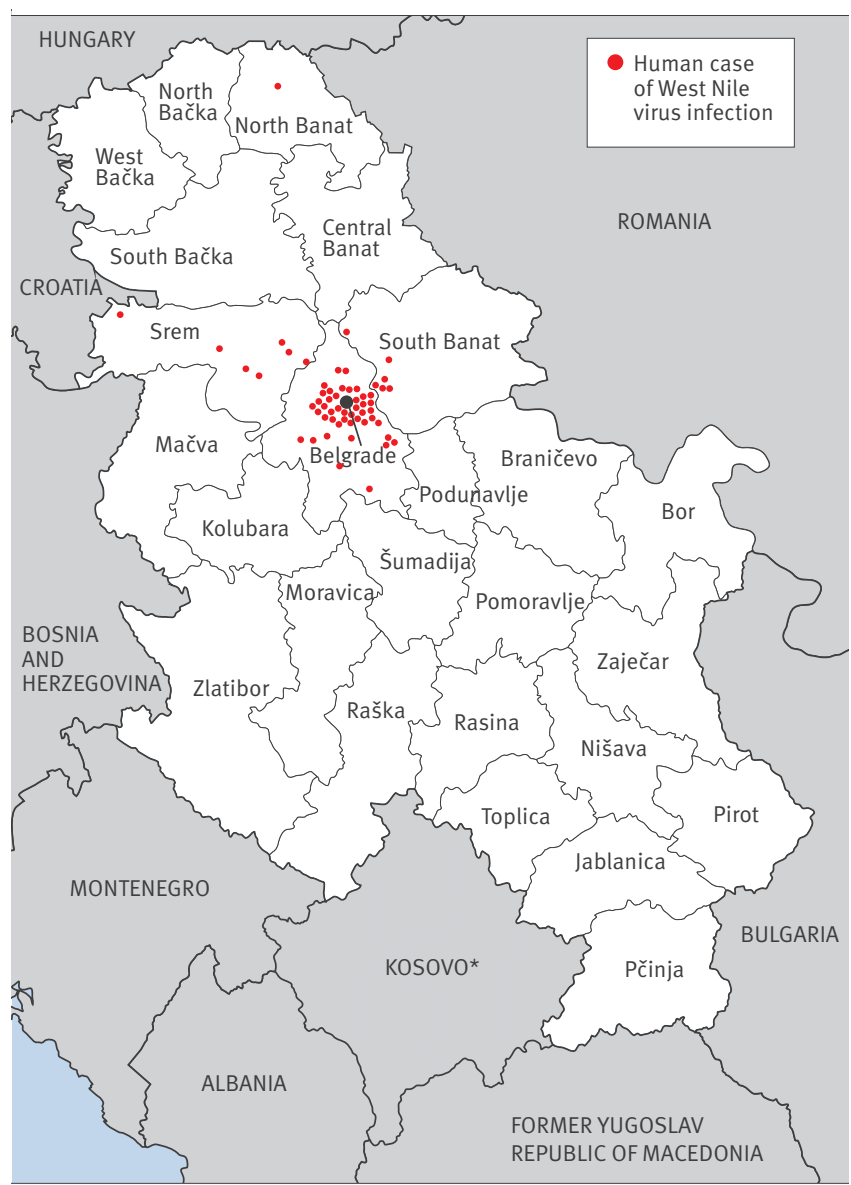

* This designation is without prejudice to positions on status, and is in line with UNSCR 1244 and the ICJ Opinion on the Kosovo Declaration of Independence.

Of the 58 patients, 32 reported spending prolonged periods of time outdoors (every day during the summer, for more than two hours per day) or close (500 metres) to a river, or living next to a river and all had had multiple mosquito bites in the three weeks before symptom onset.

The majority of patients $(n=33)$ were from Belgrade; 11 others were from Belgrade suburbs. A further seven were from the district of Srem, six from South Banat and one from North Banat (Figure 2). The first diagnosed case of WNV infection was in Pancevo, in South Banat. None of the patients had travelled abroad in the four weeks before symptom onset, except for one patient who had travelled to Montenegro (17 days before symptom onset), where no human cases of WNV infection had been reported.

Most patients $(n=52)$ had neuroinvasive disease, while six presented with mild acute febrile illness. Among the six, three presented with fever and maculopapular 
rash, one patient had pneumonia and two had a prolonged febrile illness with intensive myalgia.

Of the 52 patients with neuroinvasive disease, 44 had encephalitis and 8 meningitis. Of those with encephalitis, 10 presented with ataxia and dysmetria, suggesting rhombencephalitis, while 13 had AFP affecting one or more limbs. There were no patients with AFP without encephalitis.

The mean age of all 58 patients was 61 years (standard deviation: 15), while $33 / 44$ patients with encephalitis were over 60 years old (Table 1). Patients with encephalitis were statistically significantly older than those with mild febrile illness or meningitis ( $p<0.0001)$. Age over 60 years and immunosuppresion including diabetes were found to be associated with the development of encephalitis by univariate analysis ( $p<0.0001$ and $p=0.024$, respectively; Table 1 ), and were confirmed to be independently associated with encephalitis by multivariate logistic regression analysis after adjustment for confounders (sex, cardiovascular disease, hypertension) (OR: 44.8; 95\% Cl: 4.93-408.59; $\mathrm{p}=0.001$ (age over 60 years) and OR: 10.76;95\% Cl: 1.06-109.65; $\mathrm{p}=0.045$ (immunosuppression including diabetes)).

Cytological and biochemical analysis of CSF from the 52 patients with neuroinvasive disease revealed pleocytosis (mean: 145 leucocytes/mm³ (SD: 124), with lymphocyte predominance in 38 patients. In all 52 patients with neuroinvasive disease, the protein level was mildly elevated, at a mean of $1.09 \mathrm{~g} / \mathrm{L}$ (SD: 0.52) and the mean glucose level was normal.
The frequency of self-reported symptoms and clinical signs in the 52 patients with neuroinvasive disease are shown in Table 2.

Among patients with encephalitis, neurological manifestations, including focal neurological deficit and/or consciousness impairment, were recorded a mean of 4 days (SD: 3) after symptom onset. Consciousness impairment appeared from the first to the 1oth day of illness (median: 4th day). Among 33 patients who developed an altered state of consciousness, 13 had qualitative consciousness impairment (disorientation, confusion, agitation), while the others also had quantitative consciousness impairment (somnolence, sopor, coma). Six of the 33 had severe consciousness impairment $(\mathrm{GCS} \leq 8)$.

Respiratory failure requiring mechanical ventilation developed in 13 patients with encephalitis a mean of 12 days (SD: 6) after symptom onset (median: 11 days; range: 3-21). Five of these patients had only mild or no quantitative consciousness impairment at the time respiratory failure occurred. The mean duration of mechanical ventilation was 11 days (SD: 17) (median: 4 days; range: $2-50$ days).

Of the 58 patients, 35 had completely recovered by the time they were discharged (Figure 3). Nine patients died.

All patients who died had encephalitis: eight of the nine were over 60 years-old. The presence of acute flaccid paralysis, consciousness impairment, respiratory failure and immunosuppresion (without diabetes)

\section{TABLE 1}

Demographic characteristics of and comorbidites in patients with different forms of West Nile virus infection, Serbia, August-October $2012(\mathrm{n}=58)$

\begin{tabular}{|c|c|c|c|c|c|c|c|c|c|}
\hline \multirow[b]{2}{*}{ Characteristic } & \multirow[b]{2}{*}{$\begin{array}{l}\text { Total } \\
\mathrm{n}=58\end{array}$} & \multirow{2}{*}{$\begin{array}{c}\text { Mild } \\
\text { febrile } \\
\text { illness } \\
n=6\end{array}$} & \multirow[b]{2}{*}{$\begin{array}{l}\text { Meningitis } \\
n=8\end{array}$} & \multirow{2}{*}{$\begin{array}{c}\text { Non- } \\
\text { encephalitis } \\
n=14\end{array}$} & \multirow[b]{2}{*}{$\begin{array}{c}\text { Encephalitis } \\
\qquad n=44\end{array}$} & \multicolumn{2}{|c|}{ Univariate analysis } & \multicolumn{2}{|c|}{ Multivariate analysis } \\
\hline & & & & & & Pvalue ${ }^{a}$ & $\begin{array}{c}\mathrm{OR}^{\mathrm{a}} \\
(95 \% \mathrm{Cl})\end{array}$ & $\begin{array}{c}\mathrm{P} \\
\text { value }^{\mathrm{a}}\end{array}$ & $\begin{array}{c}\mathrm{OR}^{\mathrm{b}} \\
(95 \% \mathrm{Cl})\end{array}$ \\
\hline Mean age (SD) & $61(15)$ & $40(13)$ & $54(10)$ & $48(13)$ & $65(13)$ & $<0.001$ & - & - & - \\
\hline Aged $>60$ years & 34 & 0 & 1 & 1 & 33 & $<0.001$ & $\begin{array}{c}39.0 \\
(4.6-333.3)\end{array}$ & 0.001 & $\begin{array}{c}44.8 \\
(4.9-408.6\end{array}$ \\
\hline Male & 40 & 3 & 5 & 8 & 32 & 0.210 & $\begin{array}{c}2 \\
(0.6-7.0) \\
\end{array}$ & - & - \\
\hline $\begin{array}{l}\text { Immunosuppression } \\
\text { including diabetes }\end{array}$ & 18 & 0 & 1 & 1 & 17 & 0.024 & $\begin{array}{c}8.2 \\
(1.0-68.4)\end{array}$ & 0.045 & $\begin{array}{c}10.8 \\
(1.1-109.7)\end{array}$ \\
\hline $\begin{array}{l}\text { Immunosuppression } \\
\text { excluding diabetes }\end{array}$ & 5 & 0 & 0 & 0 & 5 & 0.237 & - & - & - \\
\hline Hypertension & 33 & 0 & 6 & 6 & 27 & 0.182 & $\begin{array}{c}2.1 \\
(0.7-7.2) \\
\end{array}$ & - & - \\
\hline $\begin{array}{l}\text { Cardiovascular } \\
\text { disease }\end{array}$ & 11 & 0 & 1 & 1 & 10 & 0.186 & $\begin{array}{c}3.8 \\
(0.4-32.9)\end{array}$ & - & - \\
\hline
\end{tabular}

$\mathrm{Cl}$ : confidence interval; OR: odds ratio; SD: standard deviation.

a Univariate analysis was performed to evaluate the difference between patients with encephalitis and those with other forms of the infection (meningitis, mild febrile illness).

b Multivariate logistic regression analysis was performed after adjustment for confounders (sex, cardiovascular disease, hypertension). 


\section{TABLE 2}

Frequency of self-reported symptoms and clinical signs in patients with neuroinvasive disease due to West Nile virus infection, Serbia, August-October $2012(\mathrm{n}=52)$

\begin{tabular}{|l|c|}
\hline Signs and symptoms & Number of patients \\
\hline Fever $\left(\geq 37.5^{\circ} \mathrm{C}\right)$ & 52 \\
\hline Neurological manifestations & 44 \\
\hline Fatigue & 40 \\
\hline Consciousness impairment & 33 \\
\hline Headache & 32 \\
\hline Vomiting & 29 \\
\hline Myalgia & 17 \\
\hline Respiratory failure & 13 \\
\hline Acute flaccid paralysis & 13 \\
\hline Diarrhoea & 9 \\
\hline Rash & 5 \\
\hline Conjunctivitis & 3 \\
\hline
\end{tabular}

were found to be associated with a fatal outcome in a univariate analysis ( $p<0.001, p=0.007, p<0.001$ and $p=0.010$, respectively) (Table 3 ).

\section{Discussion}

In Serbia, the summer of 2012 was among the warmest summers in recent years, with a dense mosquito population leading to the appearance of the first cases of human WNV infection in the country [24]. The majority of the patients were from urban regions, mainly from Belgrade and its suburbs, possibly due to specific screening in our clinic. It could also be related to the fact that Belgrade is situated at the confluence of two rivers (Danube and Sava). People enjoy swimming and other leisure activities (10-50 metres from the rivers) during the summer months and there is also a large number of houses on stilts and boat restaurants where many people gather in the summer evenings: there are dense mosquito populations by the rivers, especially in the evening [25]. Although epidemics of WNV infection were first reported in rural areas, the epidemics in Romania in 1996 and New York, United States, in 1999 demonstrated the spread of this infection in urban areas as well $[3,15]$. In our study, the majority of diagnosed patients had neuroinvasive disease, but we assume that there were more patients with WNV infection who had influenza-like febrile disease, but who did not seek medical help due to the symptoms being mild or were treated in primary care.

During the outbreaks in Israel, New York and Romania, most of those diagnosed with WNV infection had neuroinvasive disease $[2,3,15,26]$. In our study population, encephalitis was the most frequent form (in 44 of 58 patients). Similar results were reported in Romania (1996) and the United States (1999), with meningoencephalitis being present in $60-65 \%$ of patients with WNV infection with neuroinvasive disease [17]. In our study, encephalitis was seen mainly in older people and those with any kind of immunosupression including diabetes, which was also reported by Nash et al. and Murray et al. $[15,27]$.

A notable proportion of our patients with neuroinvasive disease developed AFP. In the outbreaks and Romania and Russia, paresis or paralysis was recorded in $15-20 \%$ of patients, while in the New York epidemics, the proportion of patients with paresis was notably higher, reaching $50 \%$, while about $10 \%$ had paralysis $[3,4,15,26]$.

Another symptom that was observed more often in patients with encephalitis due to WNV infection compared with patients with encephalitis caused by other pathogens was respiratory failure and the need for ventilation support. In our patients, respiratory failure mostly developed during the later stages the illness, usually around the 12th day after symptom onset. Respiratory failure during encephalitis due to WNV infection has also been described by others $[28,29]$ : it was usually not accompanied by consciousness impairment profound enough to cause central respiratory failure [29]. It has been assumed that respiratory failure in neuroinvasive disease due to WNV infection is caused by respiratory muscle weakness including both diaphragm and intercostal muscles, similar to that in poliomyelitis [30,31]. Pathological inspection of the spinal cord of patients who had died from respiratory failure in WNV infection revealed gliosis, neuronal loss and inflammation in the anterior horns of the cervical spinal cord and brainstem [32].

The case fatality rate (CFR) of $16 \%(9 / 58)$ in our study is similar to CFRs reported in the literature for WNV infection. In recent epidemics, the overall CFR was lower, ranging from $4 \%$ to $14 \%$, but higher rates were found in older patients and those with encephalitis $[4,15,20,26,33,34]$. Among patients with encephalitis, the CFR reached $18 \%$ in the United States and $24 \%$ in Israel, while CFR among patients of age over 70 years was $29 \%[15,26]$. High rates of patients with encephalitis, AFP and fatal outcome were usually observed in the first outbreaks, when the virus was introduced to a non-immune population $[15,26]$. In our study, the CFR reached $20 \%$ (9/44) in patients with encephalitis.

Veterinary and entomological investigations related to WNV have also been performed in our country. Djuricic et al. analysed 3,618 sera collected from several animal species and humans from different areas of Serbia in 2008-12, revealing that WNV was circulating in 9 of 18 tested locations in Serbia [35]. The percentage of seropositive results varied from $0.42 \%$ in Pozarevac (horses and humans) to $6.45 \%$ in Novi Pazar (dogs). Among the species tested, the highest seropositivity was registered in horses (3.97\%) [35]. Petrovic et al. examined 92 sera from 30 migratory and resident 
Functional outcome of patients at hospital discharge according to different forms of West Nile virus infection, Serbia, August-October $2012(\mathrm{n}=58)$

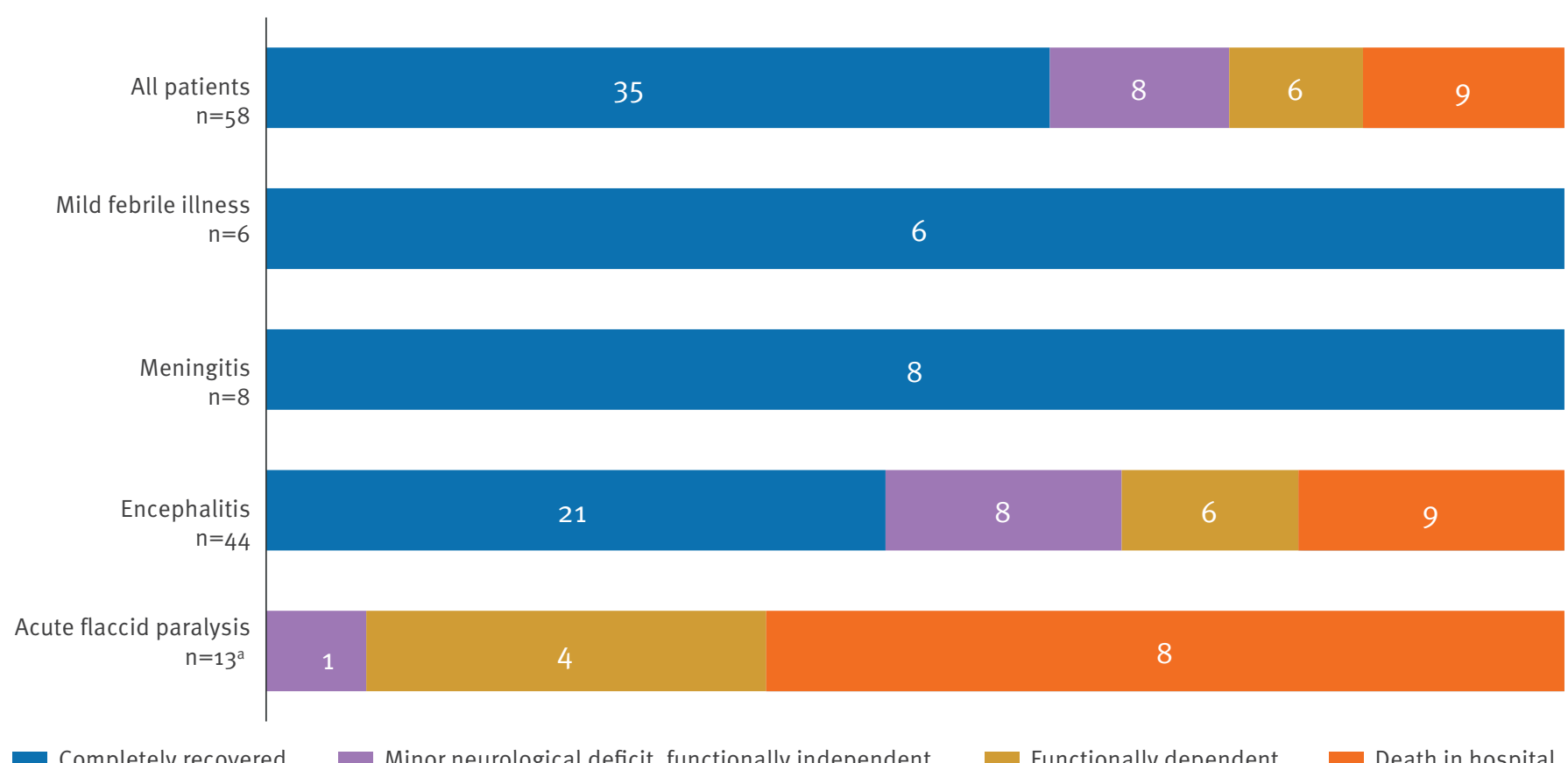

The numbers represent the number of patients with the specified outcome.

a All had encephalitis.

wild birds species collected during 2012 in Vojvodina: WNV antibodies were detected in seven samples [36]. WNV RNA was also detected in birds, mostly among raptors: genetic analysis of isolated virus strains demonstrated that they belonged to lineage II, similar to those detected in Greece and Hungary [36]. During August 2012, a total of 3,000 Culex pipiens mosquitoes were collected from three locations in Belgrade: testing of 150 pools of females confirmed the presence of WNV nucleic acid in 10 of the pools [37]. Tests in various parts of Serbia suggest that WNV is circulating not only in the area of Belgrade and Vojvodina [35]. Screening for human cases should therefore be further strengthened in summer and autumn in regions of the country not previously affected by WNV. In 2013, there were even more reported cases $(n=260)$ [38], of which 180 were treated in our clinic.

This study has some limitations. It was a single-centre study, and although it was performed at the main and largest clinic for infectious diseases in Serbia, there are other hospitals in which patients with WNV infection might have been treated. For this reason, no incidence rates could be calculated at a national or regional level. Another limitation is the small number of patients. While some of the results were statistically significant and concur with previous publications, the Cls of the ORs were wide. The study included only six patients with mild febrile illness, making it difficult to determine correlates of encephalitis. A larger sample size would be necessary for confirmation of the results. A case-control study comparing clinical characteristics of patients with encephalitis due to WNV infection with those of encephalitis patients with a different aetiology would also provide more information and might reveal specific characteristics of encephalitis due to WNV infection.

Given the number of patients with WNV infection in 2012 in Serbia, a number of public health measures were undertaken. These included intensifying activities to reduce the number of mosquitoes in indoor and outdoor environments (e.g. using insecticides, destroying mosquito habitats), systematic extermination of larvae and adult forms of mosquitoes, education of the population on how to avoid or decrease the risk of being bitten by potentially infected mosquitoes (e.g. through poster, leaflets, television and newspapers) [37]. The Ministry of Health has set up a project to detect WNV in mosquitoes in Serbia. A team from the Institute for biocides and medical ecology - comprising physicians, veterinarians and laboratory staff - will set traps to collect adult forms of mosquitoes, which will be tested for the presence of WNV (by RT$P(R)$ in urban regions and near large rivers in various parts of Serbia. Surveillance of human cases has also been improved as WNV infection became mandatorily notifiable, in August 2012. 
TABLE 3

Characteristics of patients with West Nile virus infection who died (n=9) and those who survived (n=49), Serbia, AugustOctober 2012

\begin{tabular}{|c|c|c|c|c|c|}
\hline Characteristic & $\begin{array}{l}\text { Total number of } \\
\text { patients with the } \\
\text { characteristic }\end{array}$ & $\begin{array}{l}\text { Number of } \\
\text { patients with the } \\
\text { characteristic who } \\
\text { died }\end{array}$ & $\begin{array}{c}\text { Number of } \\
\text { patients with the } \\
\text { characteristic who } \\
\text { survived }\end{array}$ & P value & OR $(95 \% \mathrm{Cl})$ \\
\hline Age $>60$ years & 34 & 8 & 26 & 0.067 & $7.1(0.8-61.0)$ \\
\hline Male & 40 & 4 & 36 & 0.119 & $0.3(0.1-1.2)$ \\
\hline $\begin{array}{l}\text { Immunouppression } \\
\text { (including diabetes) }\end{array}$ & 18 & 4 & 14 & 0.438 & $2.0(0.5-8.6)$ \\
\hline $\begin{array}{l}\text { Immunosuppression } \\
\text { (excluding diabetes) }\end{array}$ & 5 & 4 & 1 & 0.010 & $38.4(3.6-413.7)$ \\
\hline Encephalitis & 44 & 9 & 35 & 0.096 & - \\
\hline Acute flaccid paralysis & 13 & 8 & 5 & $<0.001$ & $70.4(7.2-685.1)$ \\
\hline Consciousness impairment & 33 & 9 & 24 & 0.007 & - \\
\hline Respiratory failure & 13 & 9 & 4 & $<0.001$ & - \\
\hline
\end{tabular}

$\mathrm{Cl}$ : confidence interval; OR: odds ratio.

These actions should help avoid future outbreaks of human WNV infection and raise the awareness of healthcare providers about the emergence of the virus in Serbia. In patients with mild influenza-like disease of unknown origin and those with neuroinvasive disease during late summer and early autumn, WNV should be considered a possible causative pathogen.

\section{Acknowledgements}

The authors would like to thank Professors S. Nikolić, M. Pavlović, M. Pelemiš and E. Gvozdenović who have kindly allowed us to use their patients' medical documentation. We would also like to thank $\mathrm{Dr} B$. Božovic from the Institute of Virology, Vaccines and Sera 'Torlak' and B. Grgić from the National Institute for Public Health 'Dr Milan Jovanović Batut'.

\section{Conflict of interest}

None declared.

\section{References}

1. Smithburn KC, Hughes TP, Burke AW Paul JH. A neurotropic virus isolated from the blood of a native of Uganda. Am J Trop Med. 1940; 20:471-92.

2. Murgue B, Murri S, Triki H, Deubel V, Zeller H. West Nile in Mediterranean basin: 1950-2000. Ann N Y Acad Sci. 2001;951:117-26.

http://dx.doi.org/10.1111/j.1749-6632.2001.tbo269o.x. PMid:11797769.

3. Tsai TF, Popovici F, Cernescu C, Campbell GL, Nedelcu NI. West Nile encephalitis epidemic in southeastern Romania. Lancet. 1998;352(9130):767-71. http://dx.doi.org/10.1016/ S0140-6736(98)03538-7

4. Platonov AE, Shipulin GA, Shipulina OY, Tyutyunnik EN, Frolochkina TI, Lanciotti RS, et al. Outbreak of West Nile virus infection, Volgograd Region, Russia, 1999. Emerg Infect Dis. 2001;7(1):128-32. http://dx.doi.org/10.3201/eido701.010118. PMid:11266303. PMCid:PMC2631674.

5. García-Bocanegra I, Jaén-Téllez JA, Napp S, Arenas-Montes A, Fernández-Morente M, Fernández-Molera V, et al. West Nile fever outbreak in horses and humans, Spain, 2010. Emerg Infect Dis. 2011;17(12):2397-9. http://dx.doi.org/10.3201/ eid1712.110651. PMid:22172565. PMCid:PMC3311180.

6. Barzon L, Squarzon L, Cattai M, Franchin E, Pagni S, Cusinato $\mathrm{R}$, et al. West Nile virus infection in Veneto region, Italy, 2008-2009. Euro Surveill. 2009;14(31): pii=19289. Available from: http://www.eurosurveillance.org/ViewArticle. aspx?Articleld $=19289$

7. Barzon L, Pacenti M, Cusinato R, Cattai M, Franchin E, Pagni S, et al. Human cases of west Nile Virus infection in north-eastern Italy, 15 June to 15 November 2010. Euro Surveill. 2011;16(33):pii=19949. Available from: http://www. eurosurveilance.org/ViewArticle.aspx?Articleld=19949

8. Krisztalovics K, Ferenczi E, Molnar Z, Csohan A, Ban E, Zoldi V, et al. West Nile virus infections in Hungary, AugustSeptember 2008. Euro Surveill. 2008; 13(45): pii=19030. Available from: http://www.eurosurveillance.org/ViewArticle. aspx?Articleld=19030. PMid:19000572.

9. European Centre for Disease Prevention and Control (ECDC). West Nile fever maps. Reported cases of West Nile fever for the EU and neighbouring countries. Stockholm: ECDC. [Accessed 5 Nov 2012]. Available from: http://www.ecdc.europa.eu/en/ healthtopics/west_nile_fever/west-nile-fever-maps/pages/ index.aspx

10. Danis K, Papa A, Theocharopoulos G, Douglas G, Athanasiou $M$, Detsis $M$, et al. Outbreak of West Nile virus infection in Greece, 2010. Emerg Infect Dis. 2011;17 (10):1868-72. http://dx.doi.org/10.3201/eid1710.110525. PMid:22000357. PMCid:PMC3310677.

11. Danis K, Papa A, Papanikolaou E, Dougas G, Terzaki I, Baka A, et al. Ongoing outbreak of West Nile virus infection in humans, Greece, July to August 2011. Euro Surveill. 
2011;16(34):pii=19951. Available from: http://www. eurosurveillance.org/ViewArticle.aspx?Articleld=19951

12. Kalaycioglu H, Korukluoglu G, Ozkul A, Oncul O, Tosun S, Karabay 0, et al. Emergence of west Nile virus infections in humans in Turkey, 2010 to 2011. Euro Surveill. 2012;17(21): pii=20182. Available from: http://www. eurosurveillance.org/viewarticle.aspx?Articleld=20182. PMid:22687827.

13. Onishchenko GG, Lipnitskii AV, Alekseev VV, Antonov VA, Kriuchkova TP, Krutogolovova TA. [Epidemiologic situation of West Nile fever in Russia in 2010]. Zh Mikrobiol Epidemiol Immunobiol. 2011 (3):115-20. Russian. PMid:21809655.

14. Lupulovic D, Martín-Acebes MA, Lazic S, Alonso-Padilla J, Blázquez AB, Escribano-Romero E, et al. First serological evidence of West Nile virus activity in horses in Serbia. Vector Borne Zoonotic Dis. 2011;11(9):1303-5. http://dx.doi. org/10.1089/vbz.2010.0249. PMid:21438694.

15. Nash D, Mostashari F, Fine A, Miller J, O`Leary D, Murray K, et al. The outbreak of West Nile virus infection in New York City area in 1999. N Engl J Med. 2001;344(24):1807-14. http:// dx.doi.org/10.1056/NEJM200106143442401. PMid:11407341.

16. Centre for Disease Control and Prevention (CDC). West Nile virus. Clinical evaluation \& disease. Atlanta, GA: CDC. [Accessed 5 Nov 2012]. Available from: http://www.cdc. gov/westnile/healthCareProviders/healthCareProvidersClinLabEval.html

17. Peterson LR, Marfin AA. West Nile virus: A primer for the clinician. Ann Intern Med. 2002;137(3):173-9. http://dx.doi. org/10.7326/0003-4819-137-3-200208060-00009

18. Georges AJ, Lesbordes JL, Georges-Courbot MC, Meunier DMY, Gonzales JP. Fatal hepatitis from West Nile virus. Ann Inst Pasteur Virol. 1987;138:237-44. http://dx.doi.org/10.1016/ S0769-2617(87)80007-2

19. Burt FJ, Grobbelaar AA, Leman PA, Anthony FS, Gibson GV, Swanepoel R. Phylogenetic relationships of southern African West Nile virus isolates. Emerg Infect Dis. 2002;8(8):820-6. http://dx.doi.org/10.3201/eido808.020027. PMid:12141968. PMCid:PMC2732512.

20. Sampson BA, Ambrosi C, Charlot A, Reiber K, Veress JF, Armbrustmacher V. The pathology of human West Nile virus infection. Human Pathol. 2000;31(5):527-31. http://dx.doi. org/10.1053/hp.2000.8047

21. European Center for Disease Prevention and Control (ECDC). EU case definition. Stockholm: ECDC. [Accessed 10 Oct 2012]. Available from: http://ecdc.europa.eu/en/healthtopics/west nile_fever/EU-case-definition/Pages/EU-case-definition.asp $\bar{x}$

22. Sejvar JJ. The long-term outcomes of human West Nile Virus infection. Clin Infect Dis. 2007;44 (12):1617-24. http://dx.doi. org/10.1086/518281. PMid:17516407.

23. Greenlee JE, Carroll KC. Cerebrospinal fluid in CNS Infections. In: Sheld WM, Whitley RJ, Durack DT, editors. Infections of the central nervous system. 2nd ed. Philadelphia, PA: LippincottRaven Publishers; 1997. p. 899-922.

24. Smailagic J, Savovic A, Nesic D, Milenkovic M, Zdravkovic S. Climatological analysis of summer 2012 for Serbia. Belgrade: Republic Hydrometeorological Service of Serbia, Department of National Center for Climate Changes. [Accessed $10 \mathrm{Oct}$ 2012]. Available from: http://www.hidmet.gov.rs/podaci/ meteorologija/eng/l2012.pdf

25. Stajković N, Djordjević M, Pešić B, Vidanović D, Šekler M. Vectors West Nile virus in Serbia. Proceedings of the Third International Epizootiology Days and XV Serbian Epizootiology Days, 2013 May 8-11; Niška spa, Serbia. Belgrade: Faculty of veterinary medicine Belgrade, University of Belgrade, Department for infectious diseases of animals and bee diseases FVM; 2013. p. 69-72. Available from: http://www.vet. bg.ac.rs/uploads/file/seminari_simpozijumi/Epizootioloski. dani.2013.ZBORNIK.pdf

26. Chowers MY, Lang R, Nassar F, Ben-David D, Giladi M, Rubinshtein E, et al. Clinical characteristics of the West Nile fever outbreak, Israel, 2000. Emerg Infect Dis. 2001;7(4):6758. http://dx.doi.org/10.3201/eido704.010414. http://dx.doi. org/10.3201/eido704.017414. PMid:11585531. PMCid:PMC2631759.

27. Murray K, Baraniuk S, Resnick M, Arafat R, Kilborn C, Cain K, et al. Risk factors for encephalitis and death from West Nile virus infection. Epidemiol Infect. 2006;134(6):1325-32. http:// dx.doi.org/10.1017/S0950268806006339. PMid:16672108. PMCid:PMC2870518.

28. Sejvar JJ, Bode AV, Marfin AA, Campbell GL, Ewing D, Mazowiecki M, et al. West Nile virus-associated flaccid paralysis. Emerg Infect Dis. 2005;11(7):1021-7. http:// dx.doi.org/10.3201/eid1107.040991. PMid:16022775. PMCid:PMC3371783.

29. Sejvar JJ, Bode AV, Marfin AA, Campbell GL, Pape J, Biggerstaff BJ, Petersen LR. West Nile virus-associated flaccid paralysis outcome. Emerg Infect Dis. 2006;12(3):514-6. http:// dx.doi.org/10.3201/eid1203.050643. PMid:16704798. PMCid:PMC3291435.

30. Leis AA, Stokic DS. Neuromuscular manifestations of human West Nile virus infection. Curr Treat Options Neurol. 2005;7(1):15-22. http://dx.doi.org/10.1007/s11940-005-0002-6

31. Glass JD, Samuels O, Rich MM. Poliomyelitis due to West Nile virus. N Engl J Med. 2002;347(16):1280-1. http://dx.doi. org/10.1056/NEJM200210173471616. PMid:12270972.

32. Doron SI, Dashe JF, Adelman LS, Brown WF, Werner BG, Hadley S. Histopathologically proven poliomyelitis with quadriplegia and loss of brain stem function due to West Nile infection. Clin Infect Dis. 2003;37(5):e74-7. http://dx.doi.org/10.1086/377177. PMid:12942423.

33. Weiss D, Carr D, Kellachan J, Tan C, Phillips M, Bresnitz $E$, Layton M. Clinical findings of West Nile virus infection in hospitalized patients, New York and New Jersey, 2000. Emerg Infect Dis. 2001;7(4):654-8. http://dx.doi.org/10.3201/ eid0704.017409. PMid:11589170. PMCid:PMC2631758.

34. Ceauşu E, Erşcoiu S, Calistru P, Ispas D, Dorobăt O, Homos M, et al. Clinical manifestations of the West Nile virus outbreak. Rom J Virol. 1997;48(1-4):3-11. PMid:9836323.

35. Djuricic B, Vasic A, Rogozarski D, Vojinovic D, ElezovicRadovanovic M, Manic M, et al. Mapping of West Nile infection in the Republic of Serbia: epizootiological and epidemiological investigation. Acta Vet (Beogr). Forthcoming 2013.

36. Petrovic T, Blázquez A.B, Lupulovic D, Lazic G, EscribanoRomero E, Fabijan D, et al. Monitoring West Nile virus (WNV) infection in wild birds in Serbia during 2012: first isolation and characterization of WNV strains from Serbia. Eurosurveillance. Forthcoming 2013.

37. Radivojević S, Maris S, Ljubić B, Obrenović J. First detection of West Nile fever in human population in the territory of Belgrade. Proceedings Third International Epizootiology Days and XV Serbian Epizootiology Days 2013 May 8-11; Niška spa, Serbia, Belgrade: Faculty of veterinary medicine Belgrade, University of Belgrade, Department for infectious disease of animals and bee diseases FVM; 2013. p. 61-2. Available from: http://www.vet.bg.ac.rs/uploads/file/seminari_simpozijumi/ Epizootioloski.dani.2013.ZBORNIK.pdf

38. European Centre for Disease Prevention and Control (ECDC). West Nile fever maps. Reported cases of West Nile fever for the EU and neighboring countries. Stockholm: ECDC. [Accessed 17 Oct 2013]. Available from: http://www.ecdc.europa.eu/en/ healthtopics/west_nile_fever/West-Nile-fever-maps/pages/ index.aspx 